\title{
Analysis of the zircon population and Sr-isotope data of the Paleogene igneous rocks from Kyustendil area, SW Bulgaria
}

\author{
Valentin Grozdev ${ }^{l}$, Irena Peytcheva ${ }^{1,2}$, Albrecht von Quadt ${ }^{2}$, Rossitsa Vassileva ${ }^{1}$, \\ Stoyan Georgiev ${ }^{l}$
}

${ }^{1}$ Geological Institute, Bulgarian Academy of Sciences, Acad. G. Bonchev, Bl. 24, 1113 Sofia, Bulgaria; e-mail:val.grozdev@abv.bg.

${ }^{2}$ Institute of Geochemistry and Petrology, ETH, 8092 Zurich, Switzerland.

(Accepted in revised form: November 2017)

\begin{abstract}
In the present study, we apply a combination of Sr-isotope whole-rock analyses and LA-ICP-MS $\mathrm{U}-\mathrm{Pb}$ zircon dating to understand the magmatic evolution of the igneous rocks in the Ruen Zone, western Bulgaria, and bracket the time of their formation. This approach reveals a general interval of magmatic activity from $35.57 \pm 0.27 \mathrm{Ma}$ (Pishtilski volcanics) to $28.63 \pm 0.58 \mathrm{Ma}$ (cross-cutting dykes in the Osogovo Mountain). The volcanic rocks from the Prekolnitsa Graben are formed with significant $(50 \%)$ crustal contamination/assimilation. Three major sources of crustal rocks can be outlined, with Triassic, Ordovician and Cambrian age, respectively. For the subvolcanic to plutonic magmatic rocks of the Osogovo Mountain, we suggest maturation and zircon crystallization over 2-4 Ma. The magma was generated dominantly in the continental crust and evolved through mainly fractional crystallization (FC) in the upper crustal chamber, whereas the evolution of the Osogovo dykes requires additional involvement of AFC (Assimilation and Fractional Crystallization) and contamination processes.
\end{abstract}

Grozdev, V., Peytcheva, I., von Quadt, A., Vassileva, R., Georgiev, S. 2017. Analysis of the zircon population and Sr-isotope data of the Paleogene igneous rocks from Kyustendil area, SW Bulgaria. Geologica Balcanica 46 (2), 143-151.

Keywords: Paleogene, volcanic rocks, zircon analysis, U-Pb dating, inheritance, assimilation.

\section{INTRODUCTION}

The Alpine evolution of southern Bulgaria is defined by Late Cretaceous subduction-related magmatism in the Srednogorie tectonic zone and post-subduction Cenozoic (mainly Paleogene) magmatic activity with migration of the magmatic front to paleosouth, in the Morava-Rhodope tectonic zone (e.g., Dabovski et al., 1991; von Quadt et al., 2005; Dabovski and Zagorchev, 2009). This magmatism has been studied extensively, and many aspects of its timing, general geochemical features or tectonic settings have been constrained. However, the development of new analytical techniques and accumulation of data give rise to new ideas or improvement of the existing models.

In the present work, we apply some of these techniques to the igneous rocks in the Kyustendil area, which is a part of the Ruen magmatotectonic zone (Harkovska, 1984). The latter crosscuts the bigger Morava-Rhodope tectonic zone (Dabovski and
Zagorchev, 2009), being also a part of the Macedonian-Rhodope-North Aegean volcanic zone (Dabovski et al., 1991). Significant geological constraints on the petrology and geochemistry of the rocks have been provided (Arnaudova, 1973; Harkovska, 1974; Machev, 2001a, b; Grozdev et al., 2010). The age of these magmatic rocks is well constrained as latest Eocene and early Oligocene both by their interrelations with paleontologically dated sediments (Ivanov et al., 1971) and with isotopic dating (Harkovska and Pécskay, 1997; Graf, 2001; Kounov et al., 2004, 2012; Grozdev, 2011).

We apply U-(Th)-Pb "in situ" zircon dating of the Paleogene volcanic and plutonic rocks from the Kyustendil area, which give evidence not only for the final magmatic crystallization of zircons, but provide information for the magma sources as well. In this research, we used a more detailed approach, with special attention to all available zircon crystals in the samples (the zircon population) combining zircon internal morpho- 
logy (from CL-images) with dating of magmatic rims/ grains, inherited cores and crystals. Such approach brings insights into the processes of formation of igneous rocks: with crustal assimilation/contamination or without interaction with hosting rocks. We show that the obtained zircon ages reveal the interaction of the magma with exact terranes, shedding more light on the deeper crustal levels and the outcropped basement rocks. Finally, zircon analysis is complemented with whole-rock (WR) Sr isotope data to provide an accurate assumption about the petrogenetic paths of the magma that produced the variety of intrusive, shallow intrusive and volcanic rocks in the Ruen zone of the Morava-Rhodope tectonic zone.

\section{GEOLOGICAL SETTING AND SAMPLING}

The study region is situated about $10 \mathrm{~km}$ WSW of Kyustendil Town, SW Bulgaria (Fig. 1). The Cenozoic (Paleogene) magmatic rocks crop out in the Prekolnitsa Graben (Harkovska, 1974) and the Osogovo Mountain, forming an elongated strip with NW-SE direction defined as the Ruen magmatotectonic zone (Harkovska, 1984). They intrude or overlie high- and low-grade metamorphic rocks of the Lower and Vlasina units of the Serbo-Macedonian Massif (Antic et al., 2016, and references therein) corresponding to the Ograzhden, Struma (including Osogovo-Lisets Complex: Kounov et al., 2004) and Morava units of the Morava-Rhodope tectonic zone (Dabovski and Zagorchev, 2009).

In the Prekolnitsa Graben, five stages of Cenozoic magmatic activity can be distinguished (from base to top, Fig. 1): 1) volcanic clastic and tuff material (mainly acid in composition) of the basal conglomerate formation (Harkovska, 1974); 2) Pishtilski volcanics, classified as trachyrhyodacites (Grozdev et al., 2012); 3) Gyueshevo volcanics, represented by subvolcanic bodies and flows (?) of fine to coarse porphyritic dacite to rhyolite; 4) Kopriva body, being large NW elongated coarse sanidine-phyric trachyrhyodacite; and 5) felsic rhyolite dykes, which crosscut the Kopriva body and represent the final magmatic activity in the Graben.

The Pishtilski trachyrhyodacites are extruded in the sediments of the Dolno Selo Formation. The latter are built up predominantly of sandstones (alternation of sandstones, siltstones and polymict conglomerates). These sediments are intersected and overlain by the Gyueshevo volcanics. Field relationships show

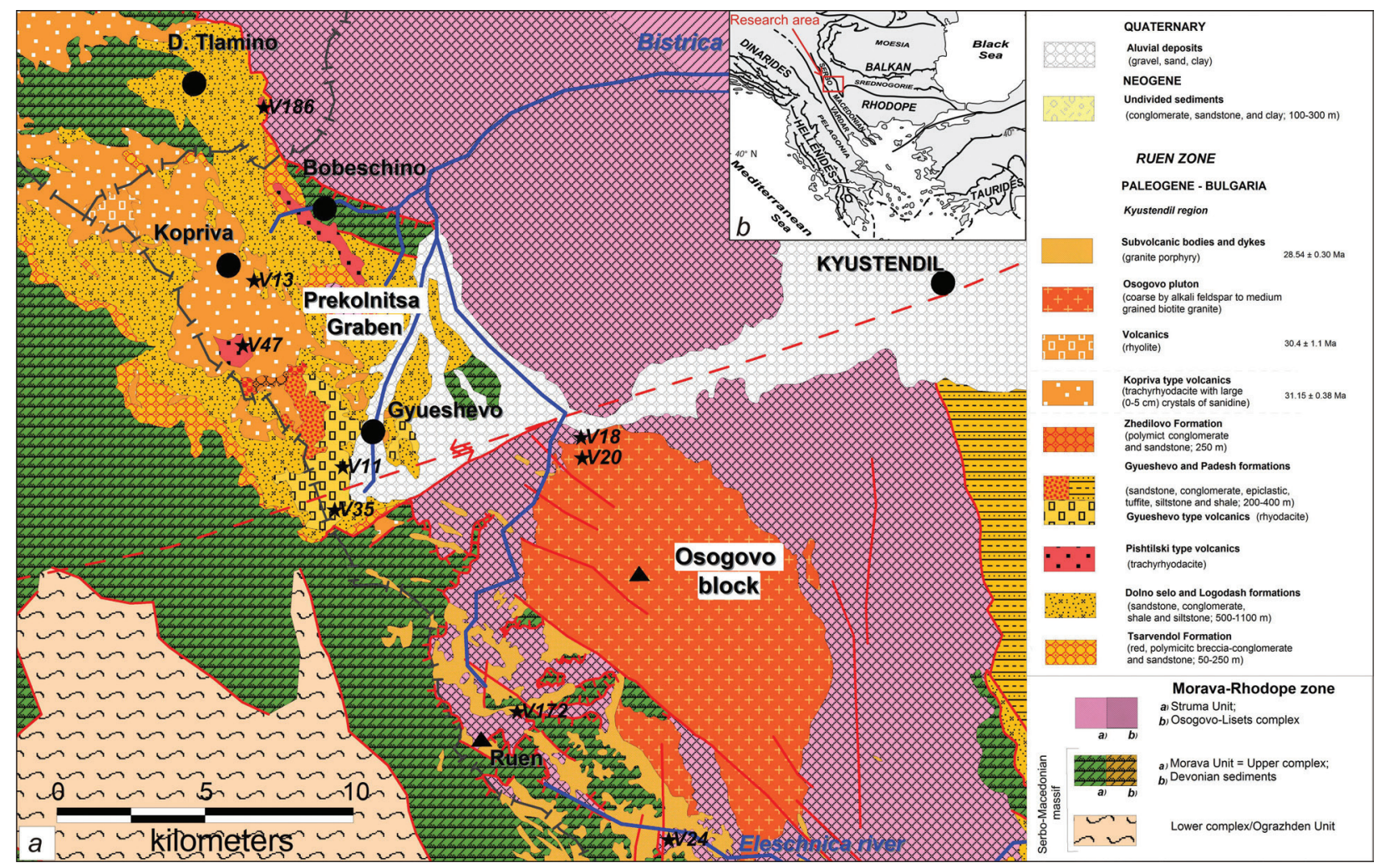

Fig. 1. Geological map of the Ruen magmatotectonic zone in Western Bulgaria (modified after Zagorchev and Ruseva, 1991) with sample localities $(a)$. Inset $(b)$ shows the location of the study area (red square within its Alpine tectonic framework). The star symbols refer to the sample numbers. 
that the Kopriva body crosscuts both the sedimentary succession (including the Pishtilski volcanics) and the Gyueshevo volcanics.

The Cenozoic magmatic activity in the southwestern slopes of the Osogovo block (Zagorchev and Ruseva, 1982) is expressed by the Osogovo granite intrusion (Fig. 1) and numerous dykes. The Osogovo granite is a relatively large plutonic body (about $150 \mathrm{~km}^{2}$ ), elongated in NW-SE direction and intruded in predominantly high-grade metamorphic rocks. Swarms of coarse sanidine-porphyry rhyolitic to granite-porphyry dykes intersect both the metamorphic basement and the Osogovo granite with the same NW-SE orientation.

The Paleogene igneous rocks of the Ruen zone are volcanic, subvolcanic and plutonic, with predominantly acid composition (Harkovska et al., 1984; see also Table 1). They are determined (Grozdev et al., 2010) as rhyodacites (Gyueshevo volcanics V11, V35), trachyrhyodacites (Kopriva volcanics, V13, V154, and Pishtilski volcanics V47, V186) and granites (Osogovo V20, V172) to granite-porphyries (dyke sample V18). On the $\mathrm{SiO}_{2}$ versus $\mathrm{K}_{2} \mathrm{O}$ diagram, they plot in the field of the high-K calc-alkaline magmatic series.

In the present study, we discuss the Pishtilski trachyrhyodacites (V47, V186), Gyueshevo rhyodacites (V11, V35), Kopriva trachyrhyodacites (V13, V154 not shown on the map), as well as the Osogovo granite (V20, V172) and granite-porphyry dykes (V18, V24; Fig. 1).

\section{ANALYTICAL METHODS}

The sample preparation and zircon separation were performed at the Geological Institute of the Bulgarian Academy of Sciences (GI-BAS) in Sofia. Zircon crystals for LA-ICP-MS U-Pb dating were embedded in epoxy-resin and the mounts (pellets) were polished to the middle of the grains prior to CL and BSE images, which were taken on a CamScan CS 4 scanning electron microscope (SEM) at ETH-Zurich equipped with an ellipsoidal mirror. The "in situ" LA-ICPMS (U-Th-Pb) analyses were performed, using both the Geolas $193 \mathrm{~nm}$ laser with Elan 6100 PE system at ETH-Zurich and the NW UP193FX excimer laser with DRC-e PE system at the Geological Institute of BAS. Energy density on sample ca $7-7.2 \mathrm{~J} \times \mathrm{cm}^{-2}$, repetition rate of $8 \mathrm{~Hz}$ and ablation craters of $35-40 \mathrm{~mm}$ were the common analytical conditions.

The GJ1 zircon standard (Jackson et al., 2004) was used as primary standard reference material (SRM) and Plesovice (Slama et al., 2008) as secondary SRM for internal control. The results were calculated offline, using GLITTER 4.0 (Macquarie University). A Th-disequilibrium correction was applied to all analyses. For each sample, all concordant zircons were used to calculate a Concordia age, or a mean ${ }^{238} \mathrm{U} /{ }^{206} \mathrm{~Pb}$ age, and probability density was plotted with the application of ISOPLOT 3.0 (Ludwig, 2003).

The whole-rock ${ }^{87} \mathrm{Sr} /{ }^{86} \mathrm{Sr}$ and ${ }^{143} \mathrm{Nd} /{ }^{144} \mathrm{Nd}$ ratios were obtained after digestion of whole-rock powder in $\mathrm{HF}$ and $\mathrm{HNO}_{3}$ and chromatographic cleaning procedure. Sr and $\mathrm{Nd}$ isotopes were analyzed on Thermo TRITONPLUS TIMS at ETH Zurich. The measured ${ }^{87} \mathrm{Sr} /{ }^{86} \mathrm{Sr}$ ratios were normalized to ${ }^{88} \mathrm{Sr} /{ }^{86} \mathrm{Sr}$ value of 8.37521. The mean ${ }^{87} \mathrm{Sr} r{ }^{86} \mathrm{Sr}$ value of the NBS 987 standard obtained during the period of measurements was $0.710252 \pm 12$.

\section{RESULTS}

The initial ${ }^{87} \mathrm{Sr} /{ }^{86} \mathrm{Sr}_{\mathrm{i}}$ data of the studied igneous rocks (calculated for an age of $30 \mathrm{Ma}$ ) are in the interval of 0.708 to 0.712 . On the diagram $\mathrm{SiO}_{2}$ versus ${ }^{87} \mathrm{Sr} /{ }^{86} \mathrm{Sr}_{\mathrm{i}}$ (Table 1, Fig. 2) two fields are clearly distinguishable: one group includes the volcanic rocks from the Pre-

Table 1

Representative Sr-isotope analyses and concentrations of $\mathrm{Sr}, \mathrm{Rb}$ and $\mathrm{SiO}_{2}$ for the igneous rocks from the Ruen Zone

\begin{tabular}{|c|c|c|c|c|c|c|c|c|}
\hline $\begin{array}{l}\text { Sample location } \\
\text { and type }\end{array}$ & $\begin{array}{l}\text { Sample } \\
\text { ID }\end{array}$ & $\begin{array}{c}\mathrm{Rb} \\
(\mathrm{ppm})\end{array}$ & $\begin{array}{c}\mathrm{Sr} \\
(\mathrm{ppm})\end{array}$ & ${ }^{87} \mathrm{Rb} /{ }^{86} \mathrm{Sr}$ & ${ }^{87} \mathrm{Sr} /{ }^{86} \mathrm{Sr}$ & $2 \sigma$ error & $\begin{array}{c}\left({ }^{87} \mathrm{Sr} r{ }^{86} \mathrm{Sr}\right)_{\mathrm{i}} \text { initial } \\
(30 \mathrm{Ma})\end{array}$ & $\begin{array}{c}\mathrm{SiO}_{2} \\
(\mathrm{wt} \%)\end{array}$ \\
\hline Kopriva & Kopriva & 255 & 663 & 1.0877 & 0.709878 & 0.000006 & 0.709415 & 70.04 \\
\hline \multirow[t]{2}{*}{ volcanics } & V154 & 274 & 567 & 1.3653 & 0.709816 & 0.000006 & 0.709234 & 68.45 \\
\hline & S198 & 218 & 466 & 1.3196 & 0.709581 & 0.000011 & 0.709019 & 68.21 \\
\hline \multirow{2}{*}{$\begin{array}{l}\text { Pishtilski } \\
\text { volcanics }\end{array}$} & V186 & 169 & 201 & 2.3850 & 0.709163 & 0.000004 & 0.708147 & 70.62 \\
\hline & V47 & 191 & 667 & 0.8087 & 0.709183 & 0.000004 & 0.708838 & 67.86 \\
\hline \multirow{2}{*}{$\begin{array}{l}\text { Gyueshevo } \\
\text { volcanics }\end{array}$} & V11 & 154 & 276 & 1.5764 & 0.711871 & 0.000005 & 0.711199 & 72.49 \\
\hline & V35 & 189 & 447 & 1.1933 & 0.712022 & 0.000004 & 0.711514 & 69.04 \\
\hline \multirow[t]{2}{*}{ Osogovo granite } & V20 & 147 & 195 & 2.1182 & 0.712028 & 0.000005 & 0.711125 & 73.95 \\
\hline & V172 & 254 & 383 & 1.8698 & 0.711942 & 0.000003 & 0.711145 & 68.90 \\
\hline \multirow[t]{2}{*}{ Granite-porphyry } & V18 & 183 & 236 & 2.1879 & 0.713167 & 0.000003 & 0.712235 & 70.69 \\
\hline & V24 & 274 & 339 & 2.2810 & 0.712894 & 0.000003 & 0.711922 & 71.00 \\
\hline
\end{tabular}




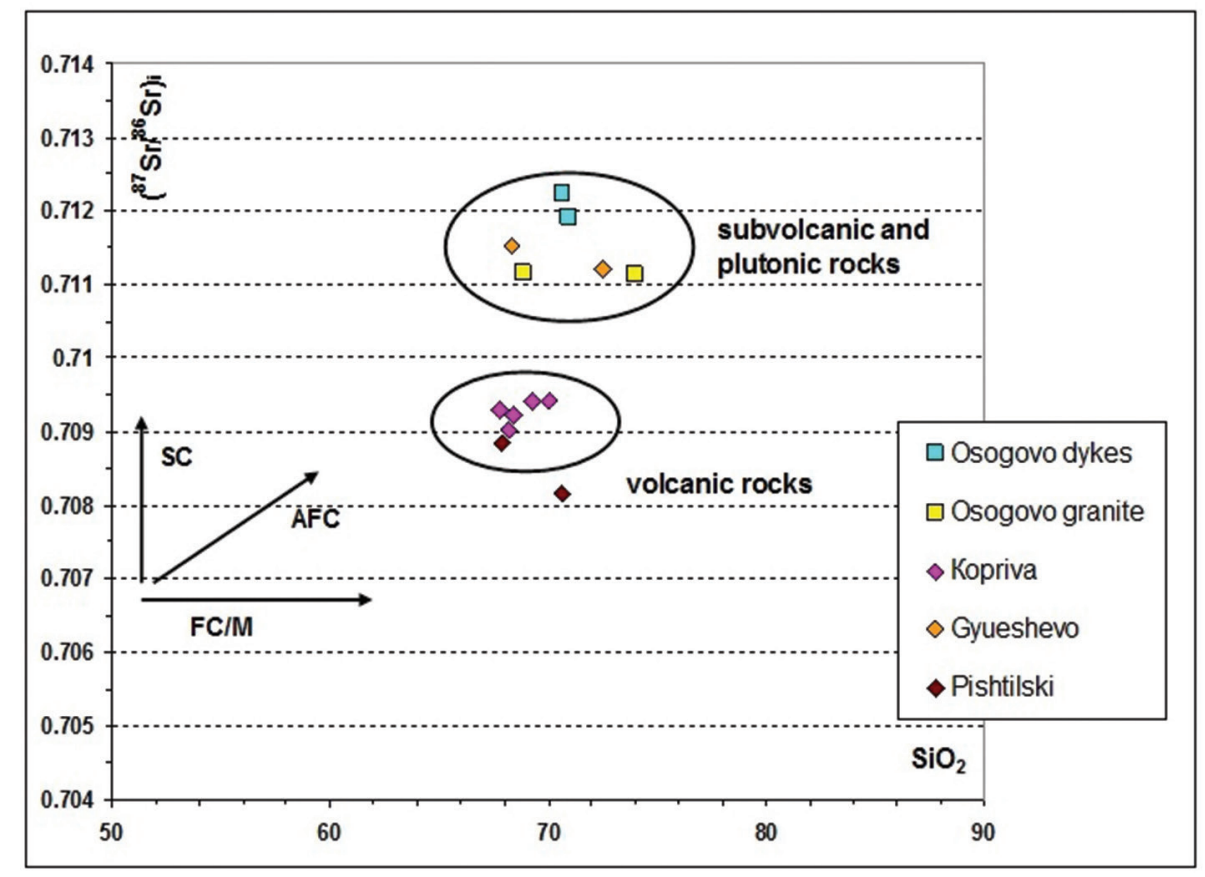

Fig. 2. $\mathrm{SiO}_{2}$ versus ${ }^{87} \mathrm{Sr} /{ }^{86} \mathrm{Sr}_{i}$ plot, informative for the magma evolution trends. Abbreviations: AFC - assimilation and fractional crystallization, $\mathrm{SC}$ - source contamination, FC/M - fractional crystallization/melting.

kolnitsa Graben, and another group is defined by the rocks of the Osogovo block.

The subvolcanic to plutonic group has similar silica content but different, more evolved initial Srisotopes ratios. Minor increase in the ${ }^{87} \mathrm{Sr}^{86} \mathrm{Sr}_{i}$ in the Kopriva volcanics infers assimilation and fractional crystallization (AFC) trend.

The position of the Osogovo granite and its dykes on the diagram gives evidence for either different crustal source (older crustal rocks with higher $\mathrm{Rb}$ content) or further assimilation of crustal material in the source. According to the diagram (Fig. 2), in the middle-upper crustal chamber the Osogovo granite (V 20, V 172) evolved through mainly FC and was less contaminated with crustal material than the granite-porphyry dykes (V18, V 24). For the latter, we may assume involvement of AFC as well. The similarity between the strontium isotope characteristics of the Osogovo intrusive and the Gyueshevo shallow intrusive rocks and volcanics is remarkable.

LA-ICP-MS zircon age data are provided in the Appendix. In the text below, we present only concordant $\mathrm{U}-\mathrm{Pb}$ zircon ages, excluding the mixed or discordant ages.

The zircon population of the Pishtilski volcanics is represented by equal amounts of Paleogene grains as autocrysts (own magmatic) zircons (Miller et al., 2007) and as Paleogene rims on older zircon grains. The calculated Concordia age of $35.57 \pm 0.27 \mathrm{Ma}$ is shown on the Concordia diagram (Fig. $3 a$ ). The older zircon cores (about $50 \%$ ) are mainly in the range of 470-550 Ma, or rarely Carboniferous (Fig. 3b).
The zircon population of the Gyueshevo volcanics is represented by $2 / 3$ Paleogene grains with significant amount of antecrysts (Fig. $3 c, d$ ). Only $1 / 3$ of all analyzed crystals are older zircon cores and grains, which represent inherited xenocrysts. The determined concordant age is $30.78 \pm 0.49 \mathrm{Ma}$. The measured older zircon ages in cores or xenocrysts define two peaks of mean ${ }^{206} \mathrm{~Pb} / 238 \mathrm{U}$ ages at around $200 \mathrm{Ma}$ and $250 \mathrm{Ma}$. Some single grains/cores were dated at 300-350 Ma and $530 \mathrm{Ma}$.

In the Kopriva volcanics (Fig. 3e, $f$ ), the Paleogene own magmatic zircons (autocrysts) without old cores represent $1 / 3$ of the analyzed grains. The majority of the Palaeogene ages were recorded as zircon rims on older (inherited) zircon crystals, which are $50 \%$ of all grains. The measured older ages belong only to old zircon cores, and xenocrysts were not observed. Two pronounced time intervals (Fig. 3f) are characteristic there: around $205 \mathrm{Ma}$ and $250 \mathrm{Ma}$, correspondingly. An obviously vast amount of antecrysts reveal several well-expressed peaks for 33-34 Ma, $36 \mathrm{Ma}$ and $40 \mathrm{Ma}$ (Fig. 3e). The youngest zircon crystallization at $29.29 \pm 0.77 \mathrm{Ma}$ is determined by two concordant zircon crystals.

The zircon populations from the Osogovo granite are dominated by own magmatic zircons, and only two older zircon cores occur with ages of $474 \mathrm{Ma}$ and 1,803 Ma, respectively. The majority of measured ages are discordant. Only four grains reveal concordant but different ages (Fig. $4 a, b$ ). Some intervals resulting from antecrysts' ages can be outlined at around $31 \mathrm{Ma}, 33 \mathrm{Ma}$ and $34 \mathrm{Ma}$. The youngest zircon age 
(obtained by one grain) is $29.55 \pm 1.03 \mathrm{Ma}$, assumed as the age of the granite.

Zircon populations from the Osogovo graniteporphyry dykes are represented by magmatic zircons mainly: auto- and antecrysts (Fig. 4d). The two older zircon cores were dated at $200 \mathrm{Ma}$ and $240 \mathrm{Ma}$, respectively. Triassic to Carboniferous (?) age of inheritance is confirmed by preliminary CA-ID-TIMS U-Pb
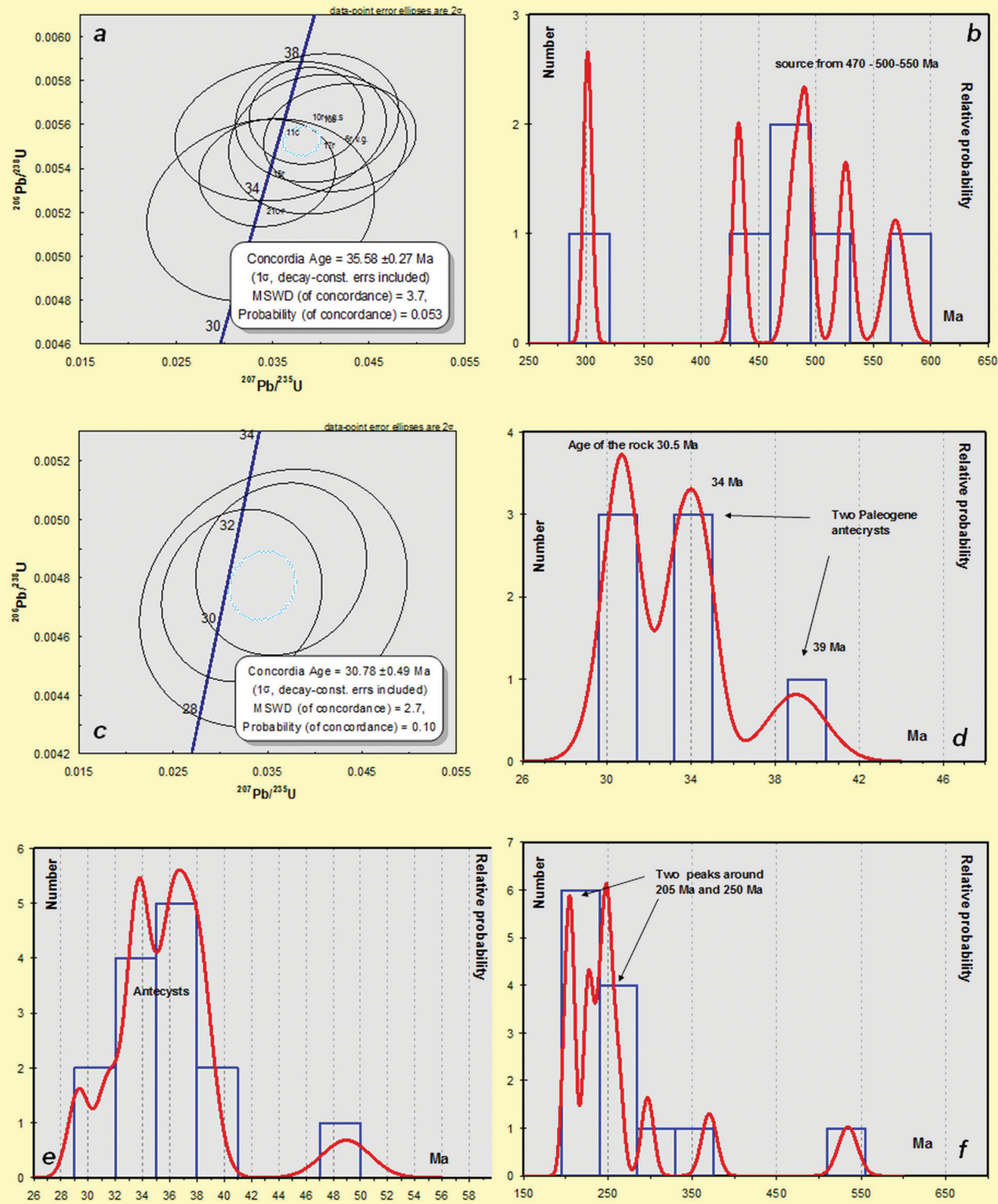

Fig. 3. $\mathrm{U} / \mathrm{Pb}$ age data and probability density plot (PDP) diagrams of the volcanic rocks from the Prekolnitsa Graben: $a$ ) Concordia diagram of the Pishtilski type; $b$ ) PDP diagram of the Pishtilski type; $c$ ) Concordia diagram of the Gyueshevo type; $d$ ) PDP diagram of the Gyueshevo type; e) data for Paleogene zircons of the Kopriva type; f) ages of inherited older zircons in the Kopriva type. 

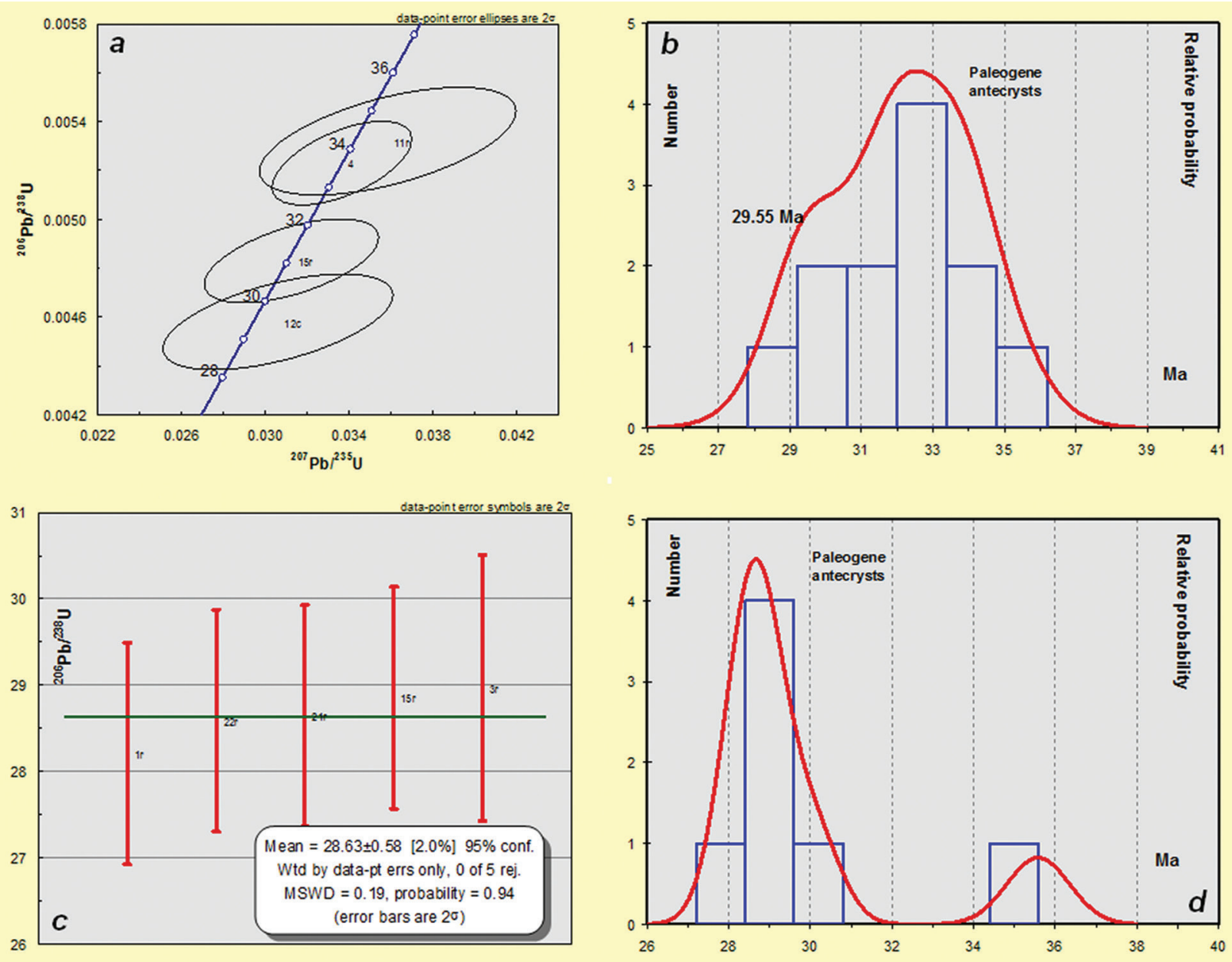

Fig. 4. $\mathrm{U} / \mathrm{Pb}$ age data and probability density plot (PDP) diagrams of the plutonic rocks from the Osogovo block: a) Concordia diagram of the Osogovo granite; b) PDP diagram of the Paleogene antecrysts of the Osogovo granite; c) weighted mean ${ }^{206} \mathrm{~Pb} /{ }^{238} \mathrm{U}$ age of the granite-porphyry dykes; $d$ ) PDP diagram showing the Paleogene antecrystic ages of the granite-porphyry dykes.

zircon dating of sample V 18. The age of the dyke is defined by five concordant grains at $28.63 \pm 0.58 \mathrm{Ma}$ ${ }^{206} \mathrm{~Pb} /{ }^{238} \mathrm{U}$ mean age; Fig. $\left.4 c\right)$. They represent the final magmatic activity in this region.

\section{DISCUSSION}

The combination of WR Sr-isotope tracing and U-Pb dating provided information about the time of the magmatism and magma evolution during its ascent through the crust and storage in middle- to upper-crustal chambers. The crystallization age of the zircons, defined by the in-situ U-Pb LA-ICP-MS method, revealed a general interval of magmatic activity from $35.57 \pm 0.27 \mathrm{Ma}$ (Pishtilski volcanics) to $28.63 \pm 0.58 \mathrm{Ma}$ (cross-cutting dykes in the Osogovo Mountain). We did not apply pretreatment of the zircons (annealing or chemical abrasion: Mattinson, 2005; von Quadt et al., 2014), and thus we consider these ages as minimum time of crystallization. Our dating (including the error uncertainties) is in good agreement with field relationships (see above) and previous publications on the stratigraphy of the Ruen Zone (Harkovska, 1974).

The zircon population analyses and age data for all studied rocks show longer zircon growth, which is documented by the vast amount of antecrysts (Fig. 3e) with ages 33-34 Ma, $36 \mathrm{Ma}$ and $38 \mathrm{Ma}$ (Figs 3, 4). This zircon characteristic suggests possible magma replenishment or reheating of the magma chamber or chambers with rejuvenation of the volcanic activity.

Evidence for magma modification processes through assimilation and contamination is provided by the analysis of the zircon population in the studied rocks. The zircon population of the Pishtilski volcanics show significant amount (about 50\%) of inherited zircons (rims and grains) from crustal rocks (units) with Early Paleozoic to Neoproterozoic age (470-550 Ma; summary in Fig. 5). This is in good agreement with the nowadays surface geology that is 


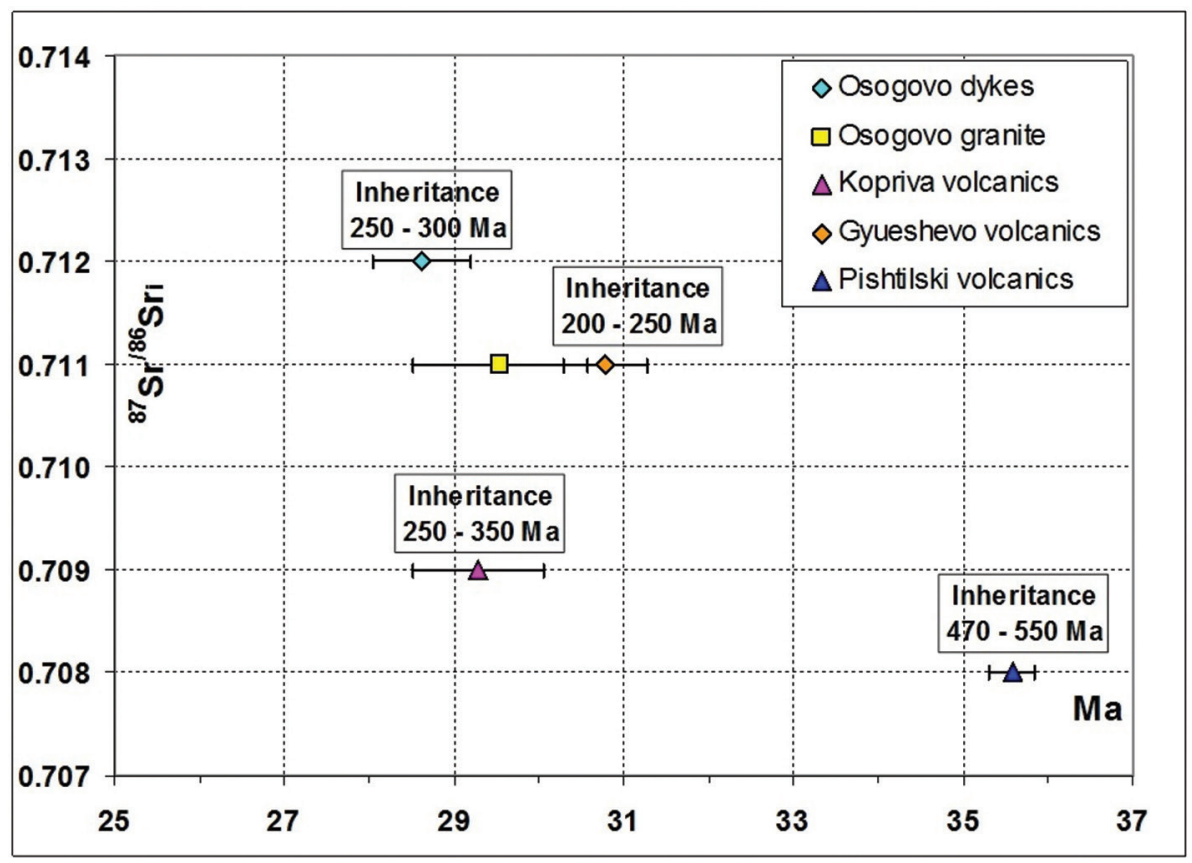

Fig. 5. Summary diagram of the LA-ICP-MS zircon age and Sr isotope data, with information about the main age of inherited cores/grains.

defined by high- and low-grade metamorphic rocks of the Lower and Vlasina Units of the Serbo-Macedonian Massif (Antic et al., 2016, and reference therein), corresponding to the Ograzhden, Struma and Morava units of the Morava-Rhodope tectonic zone (Dabovski and Zagorchev, 2009). The volcanic and subvolcanic rocks of the Gyueshevo and Kopriva, and partly the Osogovo, dykes (unpublished CAID-TIMS data) show that the inheritance (more than $50 \%$ of zircon population) is dominated by zircons of Triassic age. Triassic granitoids are mainly outcropped in the Ograzhden Unit/Vertiskos (Ograzhden batholith, Igralishte and Nikudim plutons, Skrut granite in Bulgaria and FYROM: Zidarov et al., 2007; Peytcheva et al., 2009; Georgiev et al., 2012). Evidence of Triassic magmatism in the basement was also published by Zagorchev et al. (2017). We may suggest the existence of buried (not outcropped) Triassic plutons in the deeper parts of the crust. Other sparse inherited zircons mark also Carboniferous and early-middle Proterozoic sources that may be related particularly to the high-grade rocks of the Ograzhden Unit (Peytcheva et al., 2015).

We suggest mainly AFC and SC processes in the source, and interaction of the "primary" magma with the local continental crust in the middle to upper crustal chambers, based on the strontium isotope characteristics. ${ }^{87} \mathrm{Sr} /{ }^{86} \mathrm{Sr}_{i}$ initial ratio increases slightly with crustal assimilation (Fig. 2) in the case of the Kopriva volcanics $(0.7088-0.7094)$. The very close strontium isotope characteristics argue for a common upper crustal source chamber for both the Kopriva and Pishtilski volcanics.

The considerably higher initial strontium ratio in the Gyueshevo volcanics, Osogovo granite and related dykes $(0.7112-0.7122$.) requires involvement of older crustal material with higher Rb content. Assimilation/ contamination of crustal rocks is supported by the zircon population analyses for the Gyueshevo volcanics, but not for the Osogovo granite, at least in the studied samples. This fact could be explained if we consider the Osogovo pluton as explored part of an upper crustal chamber, where the central parts are less contaminated and homogenized; there the magma evolved through fractional crystallization with very small changes in chemical (and mineral) composition, although the life of the chamber is estimated as 2-4 Ma (ante- and autocrystic zircons). The Gyueshevo volcanics and shallow intrusives may have been fed by the same chamber (as evident from the Sr-isotope ratios), but they intruded from the marginal upper parts of the chamber and were, therefore, more contaminated with zircons from host rocks.

\section{CONCLUSIONS}

(1) The Paleogene volcanic/subvolcanic rocks in the Ruen Zone, the greater part of which are actually the Kopriva trachyrhyodacites from the Prekolnitsa Graben, are formed through crustal assimilation and fractional crystallisation (AFC-process). 
(2) According to zircon population analysis, the amount of crustal input in the Kopriva volcanics is at least $50 \%$, and points to assimilation of Triassic basement rocks.

(3) The subvolcanic to plutonic acid rocks from the Osogovo Mountain and the Gyueshevo volcanics are products of one evolving, long-lived upper crustal magma chamber.

\section{Acknowledgements}

The results are supported by the SCOPES IZ73Z0 28089 project of the SNF. Assoc. Prof. Zlatka Cherneva and Acad. Ivan Zagorchev are gratefully acknowledged for constructive comments and remarks in their reviews, which substantially improved the quality of the manuscript.

\section{REFERENCES}

Antić, M., Kounov, A., Trivić, B., Wetzel, A., Peytcheva, I., von Quadt, A. 2016. Alpine thermal events in the central Serbo-Macedonian Massif (southeastern Serbia). International Journal of Earth Sciences 105 (5), 1485-1505.

Arnaudova, R. 1973. Petrographic and petrochemical features of the Osogovo Tertiary magmatites. Review of the Bulgarian Geological Society 34 (1), 19-34 (in Bulgarian)

Dabovski, C., Zagorchev, I. 2009. Introduction: Mesozoic evolution and Alpine structure. In: Dabovski, Ch., Zagorchev, I., Nikolov, T. (Eds), Geology of Bulgaria. Vol. II. Mesozoic geology. "Prof. M. Drinov" Academic Press, Sofia, 13-38 (in Bulgarian, with English abstract).

Georgiev, S., Peytcheva, I., Stefanova, E., von Quadt, A., Marchev, P., Grozdev, V., Serafimovski, T. 2012. Geochemistry and geochronology of Ilovitsa magmatic rocks, SE FYR Macedonia. International Earth Science Colloquium on the Aegean Region "IESCA-2012", Abstracts, p. 94.

Graf, J. 2001. Alpine tectonics in western Bulgaria: Cretaceous compression of the Kraiste region and Cenozoic exhumation of the crystalline Osogovo-Lisec Complex. $\mathrm{PhD}$ thesis, ETH Zurich, 185 pp. (published).

Grozdev, V. 2011. U-Pb zircon dating and zircon population analyses of the Paleogene magmatic rocks in Kyustendil area. Bulgarian Geological Society, National Conference with International Participation "Geosciences 2011", Abstracts, 57-58.

Grozdev, V., Georgiev, S., Peytcheva, I., von Quadt, A., Marchev, P. 2010. Geochemical and geochronological data on the Tertiary magmatic rocks in Kyustendil area, SW Bulgaria. Bulgarian Geological Society, National Conference with International Participation "Geosciences 2010", Abstracts, 64-65.

Grozdev, V., Peytcheva, I., von Quadt, A., Georgiev, S., Vassileva, R. 2012. ID-TIMS zircons dating, Rb-Sr and Sm-Nd isotope geochemistry of the Paleogene volcanic rocks in the Prekolnitsa graben, SW Bulgaria. Bulgarian Geological Society, National Conference with International Participation "Geosciences 2012", Abstracts, 49-50.

Harkovska, A. 1974. Structure of the Prekolnitsa graben (SW Bulgaria). Review of the Bulgarian Geological Society 35 (3), 239-251 (in Bulgarian).

Harkovska, A. 1984. Magmotectonic features of Late Paleogene volcanism in the Ruen Zone (West Bulgaria). Materials of working group 3.4 "Magmatism in the epochs of molasse-formation”, Bucharest, 63-82.

Harkovska, A., Pécskay, Z. 1997. The Tertiary magmatism in Ruen magmato-tectonic zone (W Bulgaria) - a comparison of new K-Ar ages and geological data. Proceedings of IGCP 326 Annual meeting "Magmatism, metamorphism and metallogeny of the Vardar zone and Serbo-Macedonian Massif", 137-142.
Ivanov, R., Arnaudova, R., Chernjavska, S. 1971. Geological, petrological and palynological data on the age of the Paleogene volcanic activity in western Bulgaria. Bulletin of the Geological Institute, Series Geochemistry, mineralogy and petrography 20, 243-268 (in Bulgarian).

Jackson, S.E., Pearson, N.J., Griffin, W.L., Belousova, E.A. 2004. The application of laser ablation-inductively coupled plasma-mass spectrometry to in situ U-Pb zircon geochronology. Chemical Geology 211 (1-2), 47-69.

Kounov, A., Seward, D., Bernoulli, D., Burg, J.-P., Ivanov, Z. 2004. Thermotectonic evolution of an extensional dome: the Cenozoic Osogovo-Lisets core complex (Kraishte zone, western Bulgaria). International Journal of Earth Sciences (Geologische Rundschau) 93, 1008-1024.

Kounov, A., Graf, J., von Quadt, A., Bernoulli, D., Burg, J.-P., Seward, D., Ivanov, Z., Fanning, M. 2012. Evidence for a "Cadomian" ophiolite and magmatic-arc complex in SW Bulgaria. Precambrian Research 212-213, 275-295.

Ludwig, K.R. 2003. User's manual for Isoplot 3.00. A geochronological Toolkit for Microsoft Excel. Berkeley Geochronology Center Special Publication No. 4a, 74 pp.

Machev, P. 2001a. Petrology of Osogovo pluton. Annuaire de l'Université de Sofia, Faculté de Géologie et Géographie 94 (1), 105-124 (in Bulgarian).

Machev, P. 2001b. Synplutonic dyke magmatism in Ossogovo pluton. Annuaire de l'Université de Sofia, Faculté de Géologie et Géographie 94 (1), 124-134 (in Bulgarian).

Mattinson, J.M. 2005. Zircon U-Pb chemical abrasion ("CATIMS") method: Combined annealing and multi-step partial dissolution analysis for improved precision and accuracy of zircon ages. Chemical Geology 220, 47-66.

Miller, J.S., Matzel, J.E., Miller, C.F., Burgess, S.D., Miller, R.B. 2007. Zircon growth and recycling during the assembly of large, composite arc plutons. Journal of Volcanology and Geothermal Research 167 (1-4), 282-299.

Peytcheva, I., Macheva, L., von Quadt, A., Zidarov, N. 2015. Gondwana-derived units in Ograzhden and Belasitsa Mountain, Serbo-Macedonian Massif (SW Bulgaria): combined geochemical, petrological and $\mathrm{U}-\mathrm{Pb}$ zircon-xenotime age constraints. Geologica Balcanica 44 (1-3), 51-84.

Peytcheva, I., von Quadt, A., Tarassov, M., Zidarov, N., Tarassova, E., Andreichev, V. 2009. Timing of Igralishte pluton in Ograzhden Mountain, SW Bulgaria: implications for the tectono-magmatic evolution of the region. Geologica Balcanica 38 (1-3), 5-14.

Slama, J., Kosler, J., Condon, D.J., Crowley, J.L., Gerdes, A., Hanchar, J.M., Horstwood, M.S.A., Morris, G.A., Nasdala, L., Norberg, N., Schaltegger, U., Schoene, N., Tubrett, M.N., Whitehouse, M.J. 2008. Plesovice zircon - a new natural reference material for $\mathrm{U}-\mathrm{Pb}$ and $\mathrm{Hf}$ isotopic microanalysis. Chemical Geology 249 (1-2), 1-35. 
von Quadt, A., Gallhofer, D., Guillong, M., Peytcheva, I., Waelle, M., Sakata, Sh. 2014. U/Pb dating of CA and non-CA treated zircons obtained by LA-ICP-MS and TIMS techniques: impact for their geological interpretation. Journal of Analytical Atomic Spectrometry 29, 1618-1629.

Zagorchev, I., Ruseva, M. 1982. Trusts structures in southern slope of Ossogovo mountain in Pianec region (SW Bulgaria). Geologica Balcanica 12 (3), 35-57 (in Russian).

Zagorchev, I., Ruseva, M. 1991. Geological map of the Republic of Bulgaria in scale M 1:100 000, Kriva Palanka and
Kyustendil map sheet. Committee on Geology, Company for Geophysical Surveys and Geological Mapping, Sofia.

Zagorchev, I., Balica, C., Kozhoukharova, E., Coriolan Balintoni, I. 2017. Pirin metamorphic and igneous evolution revisited in a geochronological frame based on $\mathrm{U}-\mathrm{Pb}$ zircon studies. Geologica Balcanica 46 (1), 27-63.

Zidarov, N., Tarassova, E., Peytcheva, I., von Quadt, A., Andreichev, V., Titorenkova, R. 2007. Petrology, geochemistry and age dating of Skrut granitoids - new evidence for Early Triassic magmatism in Belasitsa Mountain (SW Bulgaria). Geologica Balcanica 36 (1-2), 17-29. 